\title{
A Lagrangian analysis of the present-day sources of moisture for major ice-core sites
}

\author{
Anita Drumond ${ }^{1}$, Erica Taboada ${ }^{2}$, Raquel Nieto ${ }^{1,3}$, Luis Gimeno ${ }^{1}$, Sergio M. Vicente-Serrano ${ }^{4}$, and Juan \\ Ignacio López-Moreno ${ }^{4}$ \\ ${ }^{1}$ EPhysLab, Facultade de Ciencias, Universidade de Vigo, Ourense, 32004, Spain \\ ${ }^{2}$ Facultad de Ciencias, Universidad de La Laguna, La Laguna, 38200, Spain \\ ${ }^{3}$ Department of Atmospheric Sciences, Institute of Astronomy, Geophysics and Atmospheric Sciences, \\ University of São Paulo, São Paulo, 05508-090, Brazil \\ ${ }^{4}$ Instituto Pirenaico de Ecología, Consejo Superior de Investigaciones Científicas (IPE-CSIC), \\ Zaragoza, 38200, Spain \\ Correspondence to: Anita Drumond (anitadru@uvigo.es)
}

Received: 23 December 2015 - Published in Earth Syst. Dynam. Discuss.: 25 January 2016

Revised: 15 April 2016 - Accepted: 23 May 2016 - Published: 8 July 2016

\begin{abstract}
A Lagrangian approach was used to identify the moisture sources for 14 ice-core sites located worldwide for the period of 1980-2012. The sites were classified into three domains: Arctic, Central (Andes, Alps, and Kilimanjaro), and Antarctic. The approach was used to compute budgets of evaporation minus precipitation by calculating changes in the specific humidity along 10-day backward trajectories. The results indicate that the oceanic regions around the subtropical high-pressure centres provide most of moisture, and their contribution varies throughout the year following the annual cycles of the centres. For the Arctic Domain, the sources lie in the subtropical North Atlantic and Pacific. The subtropical South Atlantic, Indian, and Pacific oceans provide moisture for the Antarctic Domain. The sources for South America are the Atlantic and South Pacific, for Europe the sources are in the Mediterranean and the North Atlantic, and for Asia the sources are the Indian Ocean and the Arabian Sea.
\end{abstract}

\section{Introduction}

The most successful reconstruction of past climate has been due to the fact that stable water isotopes are conserved in ice cores (e.g. Jouzel et al., 1982; Dansgaard et al., 1993). The isotopic composition of precipitation, in deuterium, oxygen18 , and oxygen-17, depends on the climatic conditions prevailing in the oceanic regions where it originates (i.e. the sources), mainly the sea surface temperature and the relative humidity of air (Jouzel et al., 2013). The deuterium excess may be seen as a control parameter of air moisture trajectory history because it will change when the trajectory moves over regions, presenting different moisture conditions (e.g. sea/land, dry/wet land). Deuterium excess variations have been traditionally associated with changes in the temperature of the oceanic sources, but nowadays it is thought to be also related to changes in the relative humidity of the air in the source region (Pfahl and Sodemann, 2014). In any case, deuterium excess variations in ice cores may reflect past changes in the climate conditions of the oceanic sources (e.g. MassonDelmotte et al., 2005; Steffensen et al., 2008). This information can be very useful to understand changes linked to modifications in the atmospheric circulation because the position and conditions of the moisture sources for precipitation could be altered (e.g. Masson-Delmotte et al., 2005). That is why the knowledge on the transport of moisture is crucial for the interpretation of stable isotopes in precipitation and in palaeo-archives through the understanding of the physical climatic processes involved (Sodemann and Zubler, 2009).

The analysis of the moisture sources for regions where ice cores are settled is also important to study water resources. In the present climate, the polar ice sheets of Greenland and Antarctica are the largest freshwater reservoirs and exert some control on global sea levels (Sodemann et al., 2008). 
According to Sodemann et al. (2008), changes in the mass balance of these regions can affect the salinity of the surrounding oceans. Outside the polar latitudes, ice cores must be extracted from glaciers located at high topographic elevations. In general these regions are the headwaters of rivers, and the winter precipitation stored in these glaciers is released during the year, contributing to river runoff and water resources (Sodemann and Zubler, 2009).

The investigation of sources of moisture may be conducted using different techniques such as via the assessment of the atmospheric water balance (Peixoto and Oort, 1992), general circulation models (Delmotte et al., 2000), or trajectories (e.g. Stohl and James, 2004). Gimeno et al. (2012) summarize and compare the general techniques to identify moisture sources. During recent years, the use of Lagrangian trajectories methods has become popular for diagnosing the transport of moisture and for determining the origin of moisture that precipitates in particular regions because these methods allow a detailed budget of moisture along the trajectories (Gimeno et al., 2012). Sodemann and Stohl (2009) and Nieto et al. (2010) applied Lagrangian diagnostic schemes to identify the major sources of moisture for the principal Antarctic ice-core sites by backtracking the air masses that ultimately reached these regions over a 5-year period (20002004). Other studies have created longer back-trajectory data sets for specific ice-core sites using different Lagrangian approaches. For example, Scarchilli et al. (2011) investigated the precipitation events over the East Antarctic Ice Sheet using the HYSPLIT Lagrangian model integrated with the ERA40 data from 1980 to 2001. Markle et al. (2012) also used HYSPLIT, but integrated with NCEP/NCAR data from 1979 to 2010, to investigate the synoptic variability in the Ross Sea region, Antarctica. In this study we apply the sophisticated Lagrangian diagnostic scheme previously used by Nieto et al. (2010) over short periods to present an annual and seasonal climatology of the moisture sources for 14 of the major ice-core sites investigated worldwide for the presentday climate (1980-2012).

\section{Data and method}

Our Lagrangian approach follows the method developed by Stohl and James $(2004,2005)$ that accounts for the loss and gain of moisture along air masses trajectories. For this study we use the FLEXPART V9.0 particle dispersion model fed with ERA-Interim Reanalysis data (Dee et al., 2011), the state-of-the-art reanalysis in terms of hydrological cycle. According to the analyses of Trenberth et al. (2011) and Lorenz and Kunstmann (2012), the performance of ERA-Interim in reproducing the hydrological cycle and the water balance closure is better than ERA-40 and the newest reanalysis products Modern Era Retrospective-Analysis for Research and Applications and Climate Forecast System Reanalysis (MERRA) (Rienecker et al., 2011).
In the Lagrangian frame of reference the observer follows an individual fluid parcel as it moves through space and time. In the model the atmosphere is divided homogeneously into three-dimensional finite elements (hereafter "particles"), each representing a fraction of the total atmospheric mass (Stohl and James, 2004). These particles may be advected backward or forward in time using three-dimensional wind taken from the meteorological data (e.g. reanalysis project) every time step, with superimposed stochastic turbulent and convective motions. The rates of increase $(e)$ and decrease $(p)$ of moisture $(e-p)$ along the trajectory of each particle were calculated via changes in the specific moisture $(q)$ with time $(e-p=m \mathrm{~d} q / \mathrm{d} t)$, with $m$ being the mass of the particle. Similar to the wind field, $q$ is also taken from the meteorological data. By summing $(e-p)$ for all the particles residing in the atmospheric column over a given area $\mathrm{A}$, we obtained the surface freshwater flux $(E-P)$, where $(E)$ denotes the evaporation rate and $(P)$ denotes the precipitation rate per unit area. If we considered all the particles present in the atmospheric column, the results would be similar to the freshwater flux calculated via the Eulerian frame of reference (Stohl and James, 2004). Nevertheless, the Lagrangian methodology allows us to identify the particles affecting a particular region and to calculate the surface freshwater flux $(E-P)$ using information on the trajectories of these selected particles. In this way, a comparison between the $(E-P)$ fields generated by the Eulerian and the Lagrangian (considering only the particles affecting a particular region) approaches may indicate how similar is the moisture budget associated with the tracked particles to the freshwater flux observed at surface. A detailed description of this methodology is presented by Stohl and James (2004).

The FLEXPART data set used in this study was provided by a global experiment in which the entire global atmosphere was divided into approximately 2.0 million "particles". The tracks were computed using ERA-Interim reanalysis data at $6 \mathrm{~h}$ intervals, at a $1^{\circ}$ horizontal resolution and at a vertical resolution of 60 levels from 0.1 to $1000 \mathrm{hPa}$. The analysis covered the period from January 1980 to December 2012, and the number of particles in the globe per time step was kept constant. As stressed by Gimeno et al. (2013), the FLEXPART model requires consistent high-quality data for wind and humidity, precluding its application to older reanalysis data (pre-1979), i.e. prior to the significant decrease in the errors in these variables following the inclusion of satellite data (Bengtsson et al., 2004).

The 14 ice-core sites (hereafter target regions) investigated in the present study (Fig. 1 and Table 1) may be classified into three domains: the Arctic Domain $\left(90-60^{\circ} \mathrm{N}\right)$, which includes Greenland (GISP2, NGRIP and NEEM), Alaska (Logan, Bona-Churchill), and the Franz Josef Land archipelago (Windy Dome); the Central Domain $\left(60^{\circ} \mathrm{N}-60^{\circ} \mathrm{S}\right)$, which encompasses the South American (Huascarán and Sajama) continent, as well as Europe (Grenzgletscher), Asia (Everest), and Africa (Kilimanjaro); and finally the Antarctic Do- 

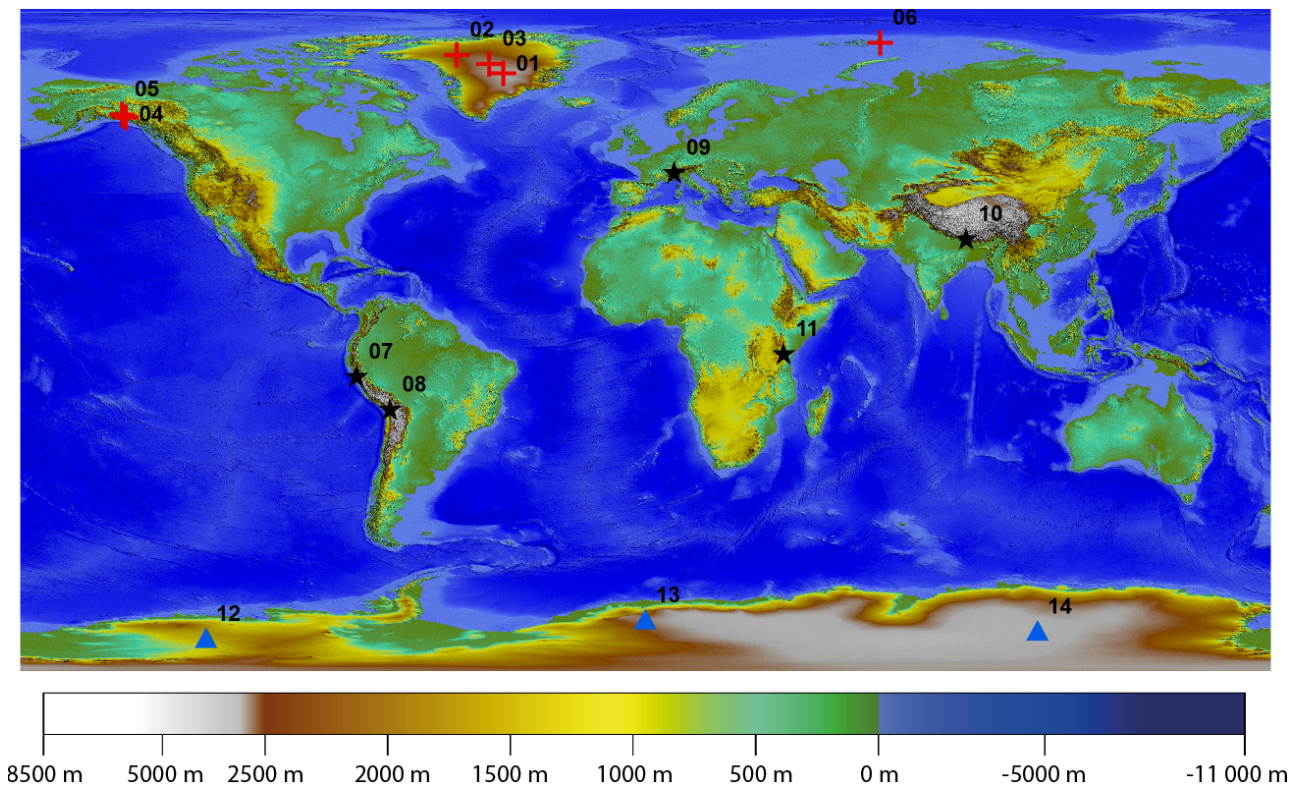

Figure 1. Topographic height (colour bar, in metres) and the location of the ice-core sites. The red crosses refer to sites in the Arctic Domain, the black stars in the Central Domain, and the blue triangles in the Antarctic Domain. The numbers are defined in Table 1.

Table 1. Characteristics of the ice-core sites analysed.

\begin{tabular}{|c|c|c|c|c|c|c|c|c|c|}
\hline Domain & No. & Site & Lat. & Long. & $\begin{array}{l}\text { Height } \\
\quad(\mathrm{m})\end{array}$ & $\begin{array}{l}\text { Max. } \\
\text { depth } \\
\text { (m) }\end{array}$ & $\begin{array}{l}\text { Temporal } \\
\text { coverage } \\
\text { (year) }\end{array}$ & $\begin{array}{l}\text { Number } \sim \\
\text { of particles } \\
\text { identified per } \\
\text { time step }\end{array}$ & Reference \\
\hline \multirow{6}{*}{ Arctic } & 1 & GISP2 & $72.60^{\circ} \mathrm{N}$ & $38.50^{\circ} \mathrm{W}$ & 3200 & $\sim 2790$ & $\sim 110000$ & 220 & Meese et al. (1997) \\
\hline & 2 & NEEM & $77.45^{\circ} \mathrm{N}$ & $51.07^{\circ} \mathrm{W}$ & 2479 & $\sim 2540$ & $\sim 108000$ & 185 & Rasmussen et al. (2013) \\
\hline & 3 & NGRIP & $75.10^{\circ} \mathrm{N}$ & $42.30^{\circ} \mathrm{W}$ & 2917 & $\sim 3084$ & $\sim 123000$ & 185 & Andersen et al. (2004) \\
\hline & 4 & Monte Logan & $60.58^{\circ} \mathrm{N}$ & $140.58^{\circ} \mathrm{W}$ & 5340 & $\sim 186$ & $\sim 8000$ & 230 & Fisher et al. (2004) \\
\hline & 5 & Bona-Churchill & $61.40^{\circ} \mathrm{N}$ & $141.70^{\circ} \mathrm{W}$ & 4420 & $\sim 460$ & $\sim 2500$ & 215 & Mashiotta et al. (2004) \\
\hline & 6 & Windy Dome & $80.78^{\circ} \mathrm{N}$ & $63.53^{\circ} \mathrm{E}$ & 580 & $\sim 315$ & $\sim 10000$ & 780 & Henderson (2002) \\
\hline \multirow{5}{*}{ Central } & 7 & Huascarán & $9.18^{\circ} \mathrm{S}$ & $78.02^{\circ} \mathrm{W}$ & 6048 & $\sim 166$ & $\sim 20000$ & 75 & Thompson et al. (1995) \\
\hline & 8 & Sajama & $18.10^{\circ} \mathrm{S}$ & $68.97^{\circ} \mathrm{W}$ & 6542 & $\sim 133$ & $\sim 20000$ & 66 & Thompson et al. (1998) \\
\hline & 9 & Grenzgletscher & $45.92^{\circ} \mathrm{N}$ & $7.87^{\circ} \mathrm{E}$ & 4200 & $\sim 125$ & $\sim 77-20$ & 150 & Eichler et al. (2000) \\
\hline & 10 & Everest & $28.02^{\circ} \mathrm{N}$ & $86.97^{\circ} \mathrm{E}$ & 6518 & $\sim 117$ & $\sim 4000$ & 70 & Hou et al. (2013) \\
\hline & 11 & Kilimanjaro & $3.13^{\circ} \mathrm{S}$ & $37.58^{\circ} \mathrm{E}$ & 5893 & $\sim 51$ & $\sim 11700$ & 80 & Thompson et al. (2002) \\
\hline \multirow{3}{*}{ Antarctic } & 12 & Byrd & $80^{\circ} \mathrm{S}$ & $119^{\circ} \mathrm{W}$ & 1530 & $\sim 2164$ & $\sim 100000$ & 450 & Thompson et al. (1975) \\
\hline & 13 & EPICA DML & $75^{\circ} \mathrm{S}$ & $0^{\circ} \mathrm{E}$ & 2892 & $\sim 2774$ & $\sim 150000$ & 1215 & Ruth et al. (2007) \\
\hline & 14 & Vostok & $78^{\circ} \mathrm{S}$ & $106^{\circ} \mathrm{E}$ & 3488 & $\sim 3623$ & $\sim 440000$ & 790 & Petit et al. (1999) \\
\hline
\end{tabular}

main $\left(60-90^{\circ} \mathrm{S}\right)$, including the Byrd, EPICA DML (Dronning Maud Land), and Vostok sites. Amongst the whole set of records available, the choice of the ice cores was a first attempt to cover the geographical distribution of the major sites available worldwide and to illustrate how our methodology can be useful for ice-core studies. Target regions were defined in the geographical locality (Table 1) of each ice-core site. Except for EPICA DML (whose area was defined by a rectangle), the target regions consisted of octagons with an equivalent radius of $100 \mathrm{~km}$ centred on each ice-core site.
Each particle identified over the target region was tracked backward in time for a period of 10 days, and its position and specific humidity $(q)$ were recorded every $6 \mathrm{~h}$. While the $10-$ day period of tracking is somewhat arbitrary, it is about the average residence time of water vapour in the global atmosphere (Numaguti, 1999). In the timeline adopted, the particles reach the ice-core sites in day 0 , and the previous days of the backward trajectories are day 1 , day $2, \ldots$, day 10 . The approximate number of particles identified every time step over each one of the 14 locations is shown in the Ta- 
ble 1. Stohl and James (2004) state that the estimate of the moisture budget is valid when the number of particles per grid column of the input meteorological data exceeds the number of the layers. With this methodology, the evaporative sources and sink regions for the particles reaching the target region can be identified. All areas where the particles gained (lost) humidity $(E-P>0)(E-P<0)$ along their trajectories towards the target region can be considered "sources of moisture" (sinks). Only source regions were considered here. For each target region, a percentile criterion was applied to the climatological annual positive $(E-P)$ field to define a threshold delimiting the spatial extent of the respective sources of moisture. The 95th percentile of the climatological annual positive $(E-P)$ values obtained for each ice-core site delimits those regions where the air masses were likely to have picked up a large amount of moisture on their transit towards the target regions. In other words, the 95th percentile criteria would show the $5 \%$ grid points with the highest positive $(E-P)$ values in the annual mean map obtained for each ice-core site. The same annual 95th percentile value was then applied to identify the spatial extent of the sources at seasonal scales.

The method is mostly limited by the use of a time derivative of the humidity (numerical errors associated with the temporal variations in the moisture present in a particle can be taken as moisture fluxes) (Stohl and James, 2004). In consequence, if the meteorological data used to drive the method do not properly close the water budget, then the method may suffer from considerable inaccuracies (Gimeno et al., 2012). Other reasons for uncertainties in the calculated trajectories are the limited resolution and uncertainties in the input reanalysis data, particularly the vertical wind component, and in the interpolation of the data (Schlosser et al., 2008; Scarchilli et al., 2011). Numerical truncation errors seem to be of minor importance (Stohl et al., 2001). Average errors of approximately $20 \%$ of the travel distance may be considered typical (Stohl et al., 2001). However, especially in areas with low meteorological data coverage, as Antarctica, trajectory errors can be larger. On one hand, Scarchilli et al. (2011) suggest that spatial uncertainties in 5-day trajectories over Antarctic are $15-30 \%$ of the total path distance, a high value probably due to the coarse grid of the meteorological model data used $\left(2.5^{\circ}\right.$ horizontal resolution and at a vertical resolution of 24 levels). On the other hand, Schlosser et al. (2008) suggest that mean errors of $20 \%$ may be typical of 5-day back trajectories over Antarctic. In spite of the uncertainties described, such random errors may cancel each other out given the large number of trajectories considered, as well as of particles found in a $1^{\circ}$ horizontal resolution atmospheric column (Stohl and James, 2004).

The methodology applied here follows the pioneers works of Stohl and James $(2004,2005)$, considering the regions of $(E-P)>0$ along the trajectories selected as moisture sources and tracking all the air masses reaching the target region independently of the occurrence of precipitation events there. Other moisture sources diagnostic schemes are available (Gimeno et al., 2012), such as the Lagrangian method proposed by Sodemann et al. (2008) to identify the origin of precipitation. In their approach, the cumulative moisture changes along the trajectory are also considered besides the net gain or loss at each grid point, which is necessary for quantifying the contribution of the air parcel for the precipitation in the target region. In any case, since the purpose of the present work is to estimate the climatological moisture sources of all air masses reaching the target regions, independently of the occurrence of precipitation in the ice-core sites, the use of this simple Lagrangian approach seems reasonable.

\section{Results}

Only the results for the annual and JJA and DJF periods are discussed here. The results for the transition seasons MAM and SON can be found in the Supplement. Figure 2 and Fig. S1 in the Supplement shows the vertically integrated moisture flux (VIMF) calculated directly from ERA-Interim. Figures 3 and S2 are based on $(E-P)$ of the tracked particles averaged over the 10-day trajectory period and redistributed on a regular $1^{\circ}$ grid, and they provide a summary of the sources of moisture for the ice-core sites.

Figure 2 shows the VIMF and the respective divergence at an annual scale, as well as for the DJF and JJA seasons. The warm (cold) colours indicate regions of maximum divergence (convergence) of the moisture flux, which may be considered to be the evaporative (precipitating) areas. The major evaporative sources around the globe coincide with the subtropical high-pressure centres observed in both hemispheres, which intensify during the respective winter seasons (DJF for the Northern Hemisphere and JJA for the Southern Hemisphere). Other regions are characterized by a strong seasonality of the VIMF divergence, such as for the monsoon domains in Asia, America, and Africa. Intense precipitation characterizes these areas during their respective summers, while divergent VIMF and evaporative conditions prevail during their respective winters.

Figure 3 summarizes the major sources of moisture for all the ice-core sites analysed at the annual scale, and for DJF and JJA. For the Arctic Domain, most of the moisture comes from latitudes $30-40^{\circ} \mathrm{N}$, coinciding with the location of the subtropical high-pressure centres, and the contribution from these sources increases during the boreal winter (DJF). The North Pacific Ocean is the major source for the sites in western North America, namely Logan (grey contour), and Bona-Churchill (yellow contour). The reader may see that the large-scale moisture transport patterns remain similar for the Logan and Bona-Churchill sites because they may be within the same or neighbouring grid points of the $1^{\circ}$ reanalysis data used in this study. The applicability of the Logan ice-core records to investigate the variability in the climate of 

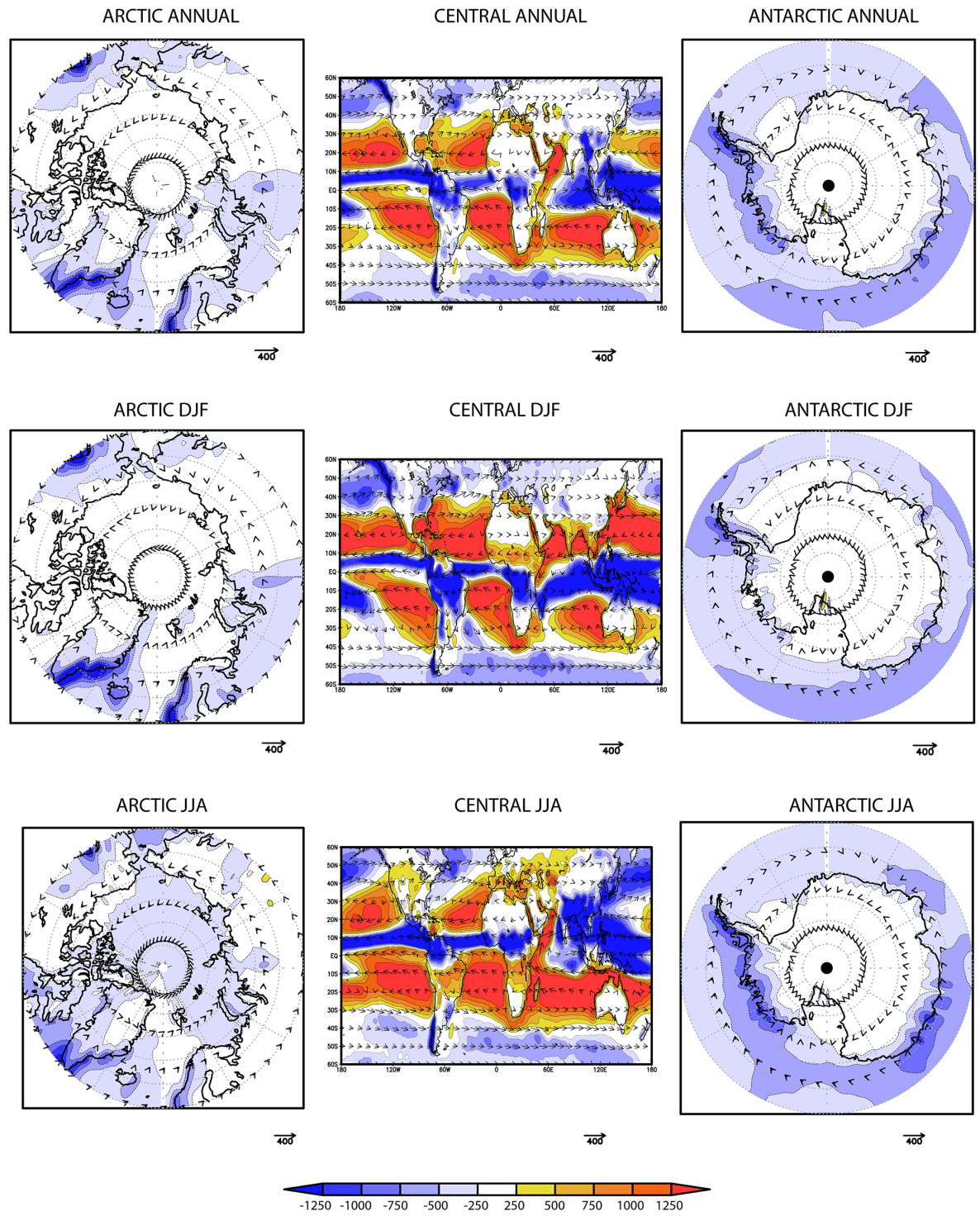

Figure 2. Vertically integrated moisture flux (vector, $\mathrm{kg} \mathrm{m}^{-1} \mathrm{~s}^{-1}$ ) and its respective divergence (shaded, $\mathrm{mm} \mathrm{yr}^{-1}$ ) in the Arctic (left-hand column), the Central (central column), and the Antarctic (right-hand column) domains for the annual (top row), DJF (central row), and JJA (bottom row) temporal means for the period 1980-2012. Data: Era-Interim.

the North Pacific Ocean was previously reported by Moore et al. (2002). The North Atlantic Ocean provides moisture for the Windy Dome (orange) and for the three sites in Greenland: GISP2 (blue), NEEM (brown), and NGRIP (violet). We note that the results obtained for Greenland agree with the findings of Sodemann et al. (2008). During JJA (boreal summer), probably associated with the predominance of dry conditions in the northern extratropical continental regions, and with the weakening of the boreal subtropical high-pressure centres and respective moisture transport, the North American continent and the Atlantic Ocean appear to be the major sources of moisture for the Greenland sites, while the moisture for the Windy Dome mainly comes from Eurasia. Using water isotopologues as tracers, Kurita (2011) suggested that the humidity source of Arctic air masses switches in early winter from locally driven to moisture transport from lower latitudes, consistently with our results.

For the Central Domain, the sources of moisture were identified for ice-core sites in the Andes, Alps, Everest, and Kilimanjaro. In the Andes (South America), the Huascarán (Fig. 3, dark blue) and Sajama (red) sites receive moisture from the Tropical Atlantic and the Eastern Pacific, and these sources show a strong seasonality. The contribution from the Pacific may be due to the presence of the South Pacific subtropical high (SPSH) and the associated southerly moisture flux over the coast (Fig. 2). The proximity of both ice-core sites to the Amazonian basin may explain the contribution from the Atlantic. According to Drumond et al. (2014) and 

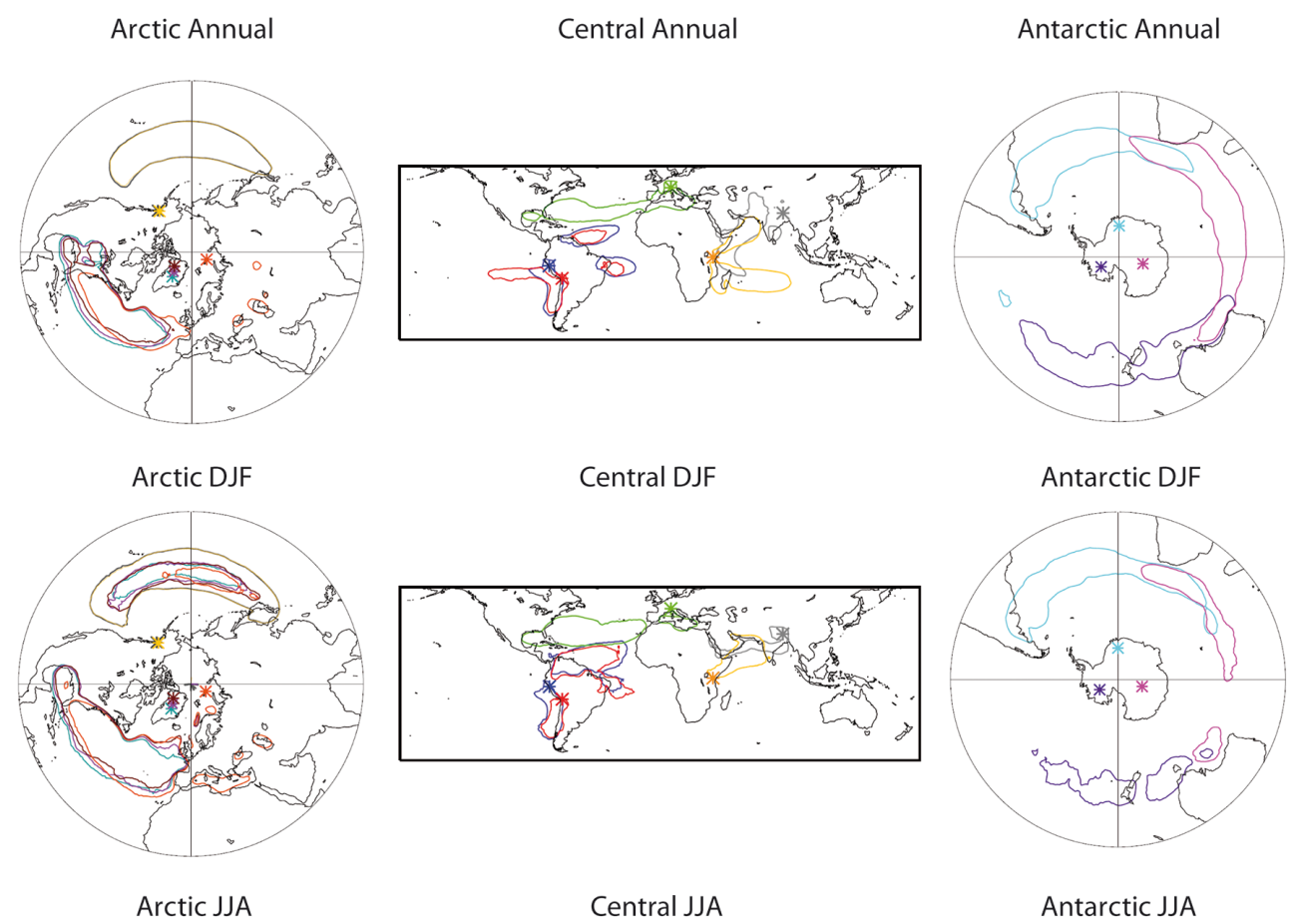

Arctic JJA

Central JJA
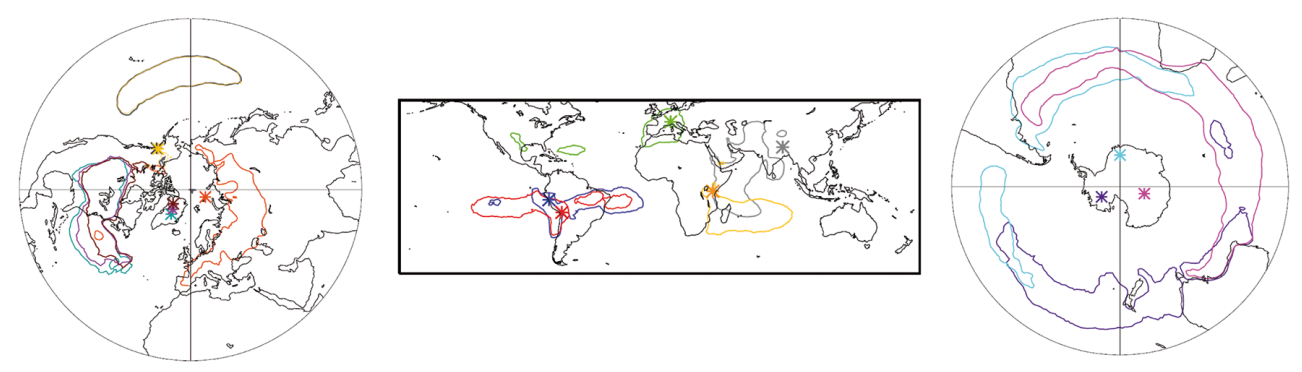

Figure 3. Moisture sources for the ice-core sites located in the Arctic (left-hand column), Central (central column), and Antarctic (right-hand column) domains for the annual (top line), DJF (central line), and JJA (bottom line) temporal means. The contour lines represent the 95th percentile of the positive $E-P$ values in the annual mean for each ice-core Lagrangian analysis. The asterisks indicate the location of the ice-core sites investigated, represented by different colours. The colours for the Arctic Domain are Logan (grey), Bona-Churchill (yellow), Windy Dome (orange), GISP2 (blue), NEEM (brown), and NGRIP (violet); for the Central Domain they are Huascarán (dark blue), Sajama (red), Grenzgletscher (green), Kilimanjaro (yellow), and Everest (grey); for the Antarctic Domain they are Byrd (purple), DML (clear blue), and Vostok (pink).

the references therein, the tropical Atlantic is the major remote moisture source for the Amazon because of the trade winds transport. Our results agree with the previous isotope analysis discussed by Thompson et al. (2000), who show that the dominant moisture source for Huascarán and Sajama is the tropical Atlantic, and water vapour is advected from the east and northeast over the Amazon. In the Pacific the source expands along the coast in DJF, and it is displaced northwards in JJA. These changes may be interpreted as a result of the migration of the SPSH northwards in JJA, which probably reduces its influence over the areas of interest (Fig. 2). In the Atlantic ocean, the contribution from the Northern Hemisphere in DJF may be related to the intensification of the Azores high and the associated moisture transport by the northerly trade winds (Fig. 2), an important mechanism of moisture transport for the South American Monsoon System (Drumond et al., 2014, 2008). During the inactive phase of the monsoon in JJA, the Azores high weakens and the South Atlantic Subtropical High (SASH) intensifies and migrates northwards, favouring moisture transport from the South Atlantic Ocean to the Andes ice-core sites.

The Grenzgletscher site (Fig. 3, green) in the Southern Alps receives moisture mainly from the Mediterranean basin but also receives it from the subtropical North Atlantic zone and the Mexican Gulf in DJF. The weakening of the VIMF divergence over the Azores high in JJA (Fig. 2) may be related to the reduction of the contribution from the Atlantic at this time. During JJA, part of the European continent is 
characterized by dry conditions, and then the land surface becomes the major moisture source for the Alps. Our results corroborate those of Sodemann and Zubler (2009), who identified the moisture sources for precipitation in the Alps using a different Lagrangian approach. They found that the Southern Alps, where the ice-core site is located, receive a large proportion of their precipitation from the Mediterranean, with considerable month-to-month variability; there is a clear change from an oceanic mode during winter to a European continental mode during summer. Agreeing with our results, Mariani et al. (2014) analysed water stable isotope ratios and net snow accumulation in the Fiescherhorn (Northern Alps) and the Grenzgletscher ice-core sites and also found that the two glaciers are influenced by different precipitation regimes, with the Grenzgletscher reflecting the characteristic precipitation regime south of the Alps and the Fiescherhorn, north of the Alps.

The Arabian Sea and the Indian Ocean are the major moisture sources for both Kilimanjaro in eastern Africa (Fig. 3, yellow) and Everest in southern Asia (Fig. 3, grey), in agreement with the major moisture sources previously identified for these regions (Gimeno et al., 2010, 2013). It is known that the characterization of the eastern African rainfall is primarily associated with the annual migration of the Intertropical Convergence Zone (ITCZ) (Camberlin and Philippon, 2002). During the inactive phase of the Indian monsoon and the migration of the ITCZ towards the Southern Hemisphere in DJF, high-pressure and VIMF divergence conditions are observed around India (Fig. 2), and the Arabian Sea acts as the major moisture source for Kilimanjaro and Everest. However, the migration of the ITCZ into the Northern Hemisphere, the intensification of the Indian subtropical high, and the active phase of the Indian monsoon in JJA favour the transport of moisture from the Southern Indian Ocean northwards (Fig. 2). In consequence, the Indian Ocean becomes the main source for Kilimanjaro and also provides moisture for Everest. The importance of the Indian Ocean in providing moisture to snowfall events in the Kilimanjaro was previously pointed out by Chan et al. (2008) through a moisture flux analysis. Making use of proxy indicators of relative moisture balance for the past millennium paired with long control simulations from coupled climate models, Tierney et al. (2013) also suggest that the Indian Ocean is the primary influence on East African rainfall over multidecadal and longer timescales. The isotope analysis of Aizen et al. (1996) reported the importance of the Indian Ocean, besides the Pacific and Atlantic Oceans, in providing moisture for the northern slope of the Himalaya and southeastern Tibet. Yao et al. (2013) also reported a strong variability intra-annual in the moisture origin of the precipitation over southern Tibetan Plateau because of the influence of the Indian monsoon system over the region.

Most of the moisture for the ice-core sites in the Antarctic Domain comes from the region around the austral subtropical high-pressure centres (Fig. 3), in good agreement with the previous findings of Nieto et al. (2010) at annual scale for a 5-year period of 2000-2004. Southern Africa and the South Atlantic are the major sources for EPICA DML (Fig. 3, clear blue). Vostok (Fig. 3, pink) receives moisture from the Indian Ocean, southern Africa, and southern Oceania. Byrd (Fig. 3, purple) also receives moisture from southern Oceania, as well as from the Pacific Ocean. In JJA the contribution from these sources is enhanced in association with the intensification of the austral high-pressure centres and the associated moisture transport. The moisture source regions appear a bit narrow in latitude compared to the results of Sodemann and Stohl (2009). These discrepancies may occur due to the differences in the methodologies. While the method applied here diagnoses the joint quantity $E-P$ of evaporation and precipitation per grid point for all air parcels reaching the target region (associate or not with precipitation), Sodemann and Stohl (2009) take the temporal sequence of moisture increases and decreases of an air parcel into account for quantitatively estimating the moisture source's contribution to the air parcel's total moisture content and hence to the precipitation generated from it over the target.

\section{Summary}

The Lagrangian approach proposed by Stohl and James (2004) was applied together with the Era-Interim data set in order to identify the major moisture sources for the present climate (1980-2012) for 14 of the more commonly investigated ice-core sites worldwide. The sites were classified into three domains (Arctic, Central, and Antarctic), and the fields of the vertically integrated moisture flux were also obtained in order to complement the analysis with an Eulerian perspective on the moisture transport.

The results shown in Fig. 3 indicate that the oceanic regions of the subtropical high-pressure centres act as the major sources of moisture, and their contribution varies throughout the year following the annual cycles of the centres. For the Arctic Domain, the main moisture sources are the subtropical North Atlantic and North Pacific. The subtropical South Atlantic, Indian, and South Pacific oceans provide moisture for the Antarctic Domain. For the Central Domain, the major sources of moisture for South America are the Atlantic and South Pacific, the North Atlantic and Mediterranean for Europe, and the Indian Ocean and the Arabian Sea for Asia and Africa.

These findings contribute to a better understanding of the moisture transport towards some of the major ice-core sites during the present climate conditions. The interannual variability of these sources and its relationship with the climatic variability modes are also information particularly interesting for the interpretation of ice-core records and it will be the theme of further research. It would also be highly valuable to calculate, based on the moisture origin, the evaporation conditions (e.g. relative humidity at sea surface temperature) and 
therefore the expected deuterium excess signal, if this were the only driver. The Lagrangian approach is interesting not only for ice-core data but also for the interpretation of water stable isotope records recently obtained from continuous, in situ monitoring of surface water vapour (e.g. Steen-Larsen et al., 2013, 2015). This combination allows both to test the validity of the back-trajectory calculation using the isotopic signals and to provide a framework to accurately investigate the meteorological drivers of isotopic fractionation.

\section{Data availability}

The ERA-Interim data set was obtained from http: //www.ecmwf.int. Please contact Anita Drumond (anitadru@uvigo.es) to request the outputs of the Lagrangian experiments.

\section{The Supplement related to this article is available online at doi:10.5194/esd-7-549-2016-supplement.}

Acknowledgements. This work was supported by the EPhysLab (UVIGO-CSIC Associated Unit). We acknowledge the support of the Spanish Government and FEDER through the "Transporte de Humedad en la Atmosfera TRAMO" (CGL-2012-35485) and the "Red de Variabilidad y Cambio Climático RECLIM" (CGL2014-517221-REDT) projects.

Edited by: M. Crucifix

\section{References}

Aizen, V., Aizen, E., Melack, J., and Martma, T.: Isotopic measurements of precipitation on central Asia glaciers (southeastern Tibetan, northern Himalayas, central Tien Shan), J. Geophys. Res., 101, 9185-9196, 1996.

Andersen, K. K., Azuma, N., Barnola, J.-M., et al.: Highresolution record of Northern Hemisphere climate extending into the last interglacial period, Nature, 431, 147-151, doi:10.1038/nature02805, 2004

Bengtsson, L., Hagemann, S., and Hodges, K. I.: Can climate trends be calculated from reanalysis data?, J. Geophys. Res., 109, D11111, doi:10.1029/2004JD004536, 2004.

Camberlin, P. and Philippon, N.: The east African March-May rainy season: associated atmospheric dynamics and predictability over the 1968-97 period, J. Climate, 15, 1002-1019, 2002.

Chan, R. Y., Vuille, M., Hardy, D. R., and Bradley, R. S.: Intraseasonal precipitation variability on Kilimanjaro and the East African region and its relationship to the large-scale circulation, Theor. Appl. Climatol., 93, 149-165, 2008.

Dansgaard, W., Johnsen, S. J., Clausen, H. B., Dahl-Jensen, D., Gundestrup, N. S., Hammer, C. U., Hvidberg, C. S., Steffensen, J. P., Sveinbjörnsdottir, A. E., Jouzel, J., and Bond, G.: Evidence for general instability of past climate from a 250-kyr ice-core record, Nature, 364, 218-220, 1993.
Dee, D. P., Uppala, S. M., Simmons, A. J., et al.: The ERAInterim reanalysis: Configuration and performance of the data assimilation system, Q. J. Roy. Meteor. Soc., 137, 553-597, doi:10.1002/qj.828, 2011.

Delmotte, M., Masson, V., Jouzel, J., and Morgan, V.: A seasonal deuterium excess signal at Law Dome, coastal Eastern Antarctica: A southern ocean signature, J. Geophys. Res., 105, 71877197, 2000.

Drumond, A., Nieto, R., Gimeno, L., and Ambrizzi, T.: A lagrangian identification of major sources of moisture over Central Brazil and La Plata Basin, J. Geophys. Res., 113, D14128, doi:10.1029/2007JD009547, 2008.

Drumond, A., Marengo, J., Ambrizzi, T., Nieto, R., Moreira, L., and Gimeno, L.: The role of the Amazon Basin moisture in the atmospheric branch of the hydrological cycle: a Lagrangian analysis, Hydrol. Earth Syst. Sci., 18, 2577-2598, doi:10.5194/hess-182577-2014, 2014.

ECMWF: ERA-Interim data set, available at: http://www.ecmwf. int, last access: 1 July 2016.

Eichler, A., Schwikowski, M., Gäggeler, H. W., Furrer, V., Synal, H.-A., Beer, J., Saurer, M., and Funk, M.: Glaciochemical dating of an ice core from upper Grenzgletscher (4200 ma.s.1.), J. Glaciol., 46, 507-515, doi:10.3189/172756500781833098, 2000.

Fisher, D. A., Wake, C., Kreutz, K., Yalcin, K., Steig, E., Mayewski, P., Anderson, L., Zheng, J., Rupper, S., Zdanowicz, C., Demuth, M., Waszkiewicz, M., Dahl-Jensen, D., Goto-Azuma, K., Bourgeois, J. B., Koerner, R. M., Sekerka, J., Osterberg, E., Abbott, M. B., Finney, B. P., and Burns, S. J.: Stable isotope records from Mount Logan, Eclipse Ice Cores and Nearby Jellybean Lake. Water cycle of the North Pacific over 2000 years and over five vertical kilometres: sudden shift and tropical connections, Geogr. Phys. Quatern., 58, 337-352, 2004.

Gimeno, L., Drumond, A., Nieto, R., Trigo, R. M., and Stohl, A.: On the origin of continental precipitation, Geophys. Res. Lett., 37, L13804, doi:10.1029/2010GL043712, 2010.

Gimeno, L., Stohl, A., Trigo, R. M., Dominguez, F., Yoshimura, K., Yu, L., Drumond, A., Durán-Quesada, A. M., and Nieto, R.: Oceanic and Terrestrial Sources of Continental Precipitation, Rev. Geophys., 50, RG4003, doi:10.1029/2012RG000389, 2012.

Gimeno, L., Nieto, R., Drumond, A., Castillo, R., and Trigo, R. M.: Influence of the intensification of the major oceanic moisture sources on continental precipitation, Geophys. Res. Lett., 40, 1443-1450, doi:10.1002/grl.50338, 2013.

Henderson, K. A.: An ice core paleoclimate study of Windy Dome, Franz Josef Land (Russia): development of a recent climate history for the Barents Sea, Dissertation, The Ohio State University, Ohio, 2002.

Hou, S., Chappellaz, J., Raynaud, D., Masson-Delmotte, V., Jouzel, J., Bousquet, P., and Hauglustaine, D.: A new Himalayan ice core $\mathrm{CH}_{4}$ record: possible hints at the preindustrial latitudinal gradient, Clim. Past, 9, 2549-2554, doi:10.5194/cp-9-2549-2013, 2013.

Jouzel, J., Merlivat, L., and Lorius, C.: Deuterium excess in an East Antarctic ice core suggests higher relative humidity at the oceanic surface during the last glacial maximum, Nature, 299, 688-691, 1982.

Jouzel, J., Delaygue, G., Landais, A., Masson-Delmotte, V., Risi, C., and Vimeux, F.: Water isotopes as tools to document oceanic 
sources of precipitation, Water Resour. Res., 49, 7469-7486, doi:10.1002/2013WR013508, 2013.

Kurita, N.: Origin of Arctic water vapor during the ice-growth season, Geophys. Res. Lett., 38, L02709, doi:10.1029/2010GL046064, 2011.

Lorenz, C. and Kunstmann, H.: The hydrological cycle in three state-of-the-art reanalyses: Intercomparison and performance analysis, J. Hydrometeorol., 13, 1397-1420, doi:10.1175/jhm-d11-088.1, 2012.

Mariani, I., Eichler, A., Jenk, T. M., Brönnimann, S., Auchmann, R., Leuenberger, M. C., and Schwikowski, M.: Temperature and precipitation signal in two Alpine ice cores over the period 19612001, Clim. Past, 10, 1093-1108, doi:10.5194/cp-10-1093-2014, 2014.

Markle, B. R., Bertler, N. A. N., Sinclair, K. E., and Sneed, S. B.: Synoptic variability in the Ross Sea region, Antarctica, as seen from back-trajectory modeling and ice core analysis, J. Geophys. Res., 117, D02113, doi:10.1029/2011JD016437, 2012.

Mashiotta, T. A., Thompson, L. G., and Davis, M. E.: The WhiteRiver Ash: New evidence from the Bona-Churchill ice corerecord, AGU Fall Meet. Suppl., 2004.

Masson-Delmotte, V., Jouzel, J., Landais, A., Stievenard, M., Johnsen, S. J., White, J. W. C., Werner, M., Sveinbjörnsdottir, A., and Fuhrer, K.: GRIP deuterium excess reveals rapid and orbital scale changes in Greenland moisture origin, Science, 309, 118-121, 2005.

Meese, D. A., Gow, A. J., Alley, R. B., Zielinski, G. A., Grootes, P. M., Ram, M., Taylor, K. C., Mayewski, P. A., and Bolzan, J. F.: The Greenland Ice Sheet Project 2 depth-age scale: Methods and results, J. Geophys. Res., 102, 26411-26423, doi:10.1029/97JC00269, 1997.

Moore, G. W. K., Holdsworth, G., and Alverson, K.: Variability in the climate of the Pacific Ocean and North America as expressed in the Mount Logan ice core, Ann. Glaciol., 35, 423-429, 2002.

Nieto, R., Durán-Quesada, A. M., and Gimeno, L.: Major sources of moisture for Antarctic ice-core sites identified through a Lagrangian approach, Clim. Res., 40, 45-49, doi:10.3354/cr00842, 2010 .

Numaguti, A.: Origin and recycling processes of precipitating water over the Eurasian continent: Experiments using an atmospheric general circulation model, J. Geophys. Res., 104, 1957-1972, 1999.

Peixoto, J. P. and Oort, A. H.: Physics of climate, American Institute of Physics, New York, 1992.

Petit, J. R., Jouzel, J., Raynaud, D., Barkov, N. I., Barnola, J.-M., Basile, I., Bender, M., Chappellaz, J., Davis, M., Delaygue, G., Delmotte, M., Kotlyakov, V. M., Legrand, M., Lipenkov, V. Y., Lorius, C., PÉpin, L., Ritz, C., Saltzman, E., and Stievenard, M.: Climate and atmospheric history of the past 420,000 years from the Vostok ice core, Antarctica, Nature, 399, 429-436, 1999.

Pfahl, S. and Sodemann, H.: What controls deuterium excess in global precipitation?, Clim. Past, 10, 771-781, doi:10.5194/cp10-771-2014, 2014.

Rasmussen, S. O., Abbott, P. M., Blunier, T., Bourne, A. J., Brook, E., Buchardt, S. L., Buizert, C., Chappellaz, J., Clausen, H. B., Cook, E., Dahl-Jensen, D., Davies, S. M., Guillevic, M., Kipfstuhl, S., Laepple, T., Seierstad, I. K., Severinghaus, J. P., Steffensen, J. P., Stowasser, C., Svensson, A., Vallelonga, P., Vinther, B. M., Wilhelms, F., and Winstrup, M.: A first chronology for the
North Greenland Eemian Ice Drilling (NEEM) ice core, Clim. Past, 9, 2713-2730, doi:10.5194/cp-9-2713-2013, 2013.

Rienecker, M. M., Suarez, M. J, Gelaro, R., Todling, R., Bacmeister, J., Liu, E., Bosilovich, M. G., Schubert, S. D. Takacs, L., Kim, G.-K., Bloom, S., Chen, J., Collins, D., Conaty, A., da Silva, A., Gu, W., Joiner, J., Koster, R. D., Lucchesi, R., Molod, A., Owens, T., Pawson, S., Pegion, P., Redder, C. R., Reichle, R., Robertson, F. R., Ruddick, A. G., Sienkiewicz, M., and Woollen, J.: MERRA: NASA's Modern-Era Retrospective Analysis for Research and Applications, J. Climate, 24, 3624-3648, doi:10.1175/JCLI-D-11-00015.1, 2011.

Ruth, U., Barnola, J.-M., Beer, J., Bigler, M., Blunier, T., Castellano, E., Fischer, H., Fundel, F., Huybrechts, P., Kaufmann, P., Kipfstuhl, S., Lambrecht, A., Morganti, A., Oerter, H., Parrenin, F., Rybak, O., Severi, M., Udisti, R., Wilhelms, F., and Wolff, E.: "EDML1": a chronology for the EPICA deep ice core from Dronning Maud Land, Antarctica, over the last 150000 years, Clim. Past, 3, 475-484, doi:10.5194/cp-3-475-2007, 2007.

Scarchilli, C., Frezzotti, M., and Ruti, P. M.: Snow precipitation at four ice core sites in East Antarctica: provenance, seasonality and blocking factors, Clim. Dynam., 37, 2107-2125, doi:10.1007/s00382-010-0946-4, 2011.

Schlosser, E., Oerter,H., Masson-Delmotte, V., and Reijmer C.: Atmospheric influence on the deuterium excess signal in polar firn: Implications for ice-core interpretation, J. Glaciol., 54, 117-124, doi:10.3189/002214308784408991, 2008.

Sodemann, H. and Stohl, A.: Asymmetries in the moisture origin of Antarctic precipitation, Geophys. Res. Lett., 36, L22803, doi:10.1029/2009GL040242, 2009.

Sodemann, H. and Zubler, E.: Seasonal and inter-annual variability of moisture sources for Alpine precipitation during 1995-2002, Int. J. Climatol., 30, 947-961, doi:10.1002/joc.1932, 2009.

Sodemann, H., Schwierz, C., and Wernli, H.: Interannual variability of Greenland winter precipitation sources: Lagrangian moisture diagnostic and North Atlantic Oscillation influence, J. Geophys. Res., 113, D12111, doi:10.1029/2007JD009416, 2008.

Steen-Larsen, H. C., Johnsen, S. J., Masson-Delmotte, V., Stenni, B., Risi, C., Sodemann, H., Balslev-Clausen, D., Blunier, T., Dahl-Jensen, D., Ellehøj, M. D., Falourd, S., Grindsted, A., Gkinis, V., Jouzel, J., Popp, T., Sheldon, S., Simonsen, S. B., Sjolte, J., Steffensen, J. P., Sperlich, P., Sveinbjörnsdóttir, A. E., Vinther, B. M., and White, J. W. C.: Continuous monitoring of summer surface water vapor isotopic composition above the Greenland Ice Sheet, Atmos. Chem. Phys., 13, 4815-4828, doi:10.5194/acp-13-4815-2013, 2013.

Steen-Larsen, H. C., Sveinbjörnsdottir, A. E., Jonsson, Th., Ritter, F., Bonne, J.-L., Masson-Delmotte, V., Sodemann, H., Blunier, T., Dahl-Jensen, D., Vinther, B. M.: Moisture sources and synoptic to seasonal variability of North Atlantic water vapor isotopic composition, J. Geophys. Res.-Atmos., 120, 5757-5774, doi:10.1002/2015JD023234, 2015.

Steffensen, J. P., Andersen, K. K., Bigler, M., Clausen, H. B., DahlJensen, D., Fischer, H., Goto-Azuma, K., Hansson, M., Johnsen, S. J., Jouzel, J., Masson-Delmotte, V., Popp, T., Rasmussen, S. O., Roethlisberger, R., Ruth, U., Stauffer, B., SiggaardAndersen, M.-L., Sveinbjornsdottir, A. E., Svensson, A., and White, J. W. C.: High-resolution Greenland Ice Core data show abrupt climate change happens in few years, Science, 321, 680 684, doi:10.1126/science.1157707, 2008. 
Stohl, A. and James, P.: A Lagrangian Analysis of the Atmospheric Branch of the Global Water Water Cycle. Part I: Method Description, Validation and Demonstration for the August 2002 Flooding in Central Europe, J. Hydrometeorol., 5, 656-678, 2004.

Stohl, A. and James, P.: A Lagrangian analysis of the atmospheric branch of the global water cycle. II. Moisture transports between Earth's ocean basins and river catchments, J. Hydrometeorol., 6, 961-984, 2005.

Stohl, A., Heimberger, L., Scheele, M. P., and Wernli, H.: An intercomparison of results from three trajectory models, Meteorol. Appl., 8, 127-135, 2001.

Tierney, J. E., Smerdon, J. E., Anchukaitis, K. J., and Seager, R.: Multidecadal variability in East African hydroclimate controlled by the Indian Ocean, Nature, 493, 389-392, 2013.

Thompson, L. G., Hamilton, W. L., and Bull, C.: Climatological implications of microparticle concentrations in the ice core from Byrd Station, Western Antarctica, J. Glaciol., 14, 433-444, 1975.

Thompson, L. G., Mosley-Thompson, E., Davis, M. E., Lin, P.-N., Henderson, K. A., Cole-Dai, J., Bolzan, J. F., and Liu, K-b.: Late Glacial Stage and Holocene tropical ice core records from Huascaran, Peru, Science, 269, 46-50, 1995.

Thompson, L. G., Davis, M. E., Thompson, E. M., Sowers, T. A., Henderson, K. A., Zagorodnov, V. S., Lin, P. N., Mikhalenko, V. N., Campen, R. K., Bolzan, J. F., Cole-Dai, J., and Francou, B.: A 25,000 year tropical climate history from Bolivian ice cores, Science, 282, 1858-1864, 1998.
Thompson, L. G., Mosley-Thompson, E., and Henderson K. A.: Ice core paleoclimate records in tropical South America since the Last Glacial Maximum, Journal of Quaternary Science, 15, 377394, 2000.

Thompson, L. G., Mosley-Thompson, E., Davis, M. E., Henderson, K. A., Brecher, H. H., Zagorodnov, V. S., Mashiotta, T. A., Lin, P.-N., Mikhalenko, V. N., Hardy, D. R., and Beer, J.: Kilimanjaro Ice core Records: Evidence of Holocene climate change in Tropical Africa, Science, 298, 589-593, doi:10.1126/science.1073198, 2002.

Trenberth, K. E., Fasullo, J. T., and Mackaro, J.: Atmospheric moisture transports from ocean to land and global energy flows in reanalyses, J. Climate, 24, 4907-4924, doi:10.1175/2011jcli4171.1, 2011.

Yao, T., Masson-Delmotte, V., Gao, J., Yu, W., Yang, X., Risi, C., Sturm, C., Werner, M., Zhao, H., He, Y., Ren, W., Tian, L., Shi, C., and Hou, S.: A review of climatic controls on $\delta^{18} \mathrm{O}$ in precipitation over the Tibetan Plateau: Observations and simulations, Rev. Geophys., 51, 525-548, doi:10.1002/rog.20023, 2013. 